\title{
The fish species composition and variation of catch from the small-scale gillnet fishery before, during and after the 1997-1998 ENSO event, central Mexican Pacific
}

\author{
J.A. Rojo-Vázquez ${ }^{1}$, C. Quiñonez-Velázquez ${ }^{3}$, H.A. Echavarria-Heras ${ }^{2}$, G. Lucano-Ramírez ${ }^{1}$, \\ E. Godínez-Domínguez, S. Ruiz-Ramírez ${ }^{1}$, V.H. Galván-Piña ${ }^{1} \&$ O. Sosa-Nishizaki ${ }^{2}$ \\ 1 Departamento de Estudios para el Desarrollo Sustentable de Zonas Costeras, Universidad de Guadalajara, Gómez \\ Farias \# 82, San Patricio-Melaque, Jalisco, México; jrojo@costera.melaque.udg.mx. Phone (315) 355-6330, Fax: \\ (315) 355-6331. \\ 2 CICESE - Departamento de Ecología, Km 107 Carr., Tijuana-Ensenada, Ensenada, B.C. México. hechavar@cicese.mx \\ 3 CICIMAR - Departamento de Pesquerías, Av. Instituto Politécnico Nacional s/n, Col. Playa Palo de Santa Rita, La \\ Paz, B.C.S., México. cquinone@ipn.mx
}

Received 06-VII-2006. C Corrected 15-II-2007. Accepted 22-VIII-2007.

\begin{abstract}
In the tropical and subtropical coastal zone, were highly diverse fish communities occur, it is important to study the small scale fisheries exploiting these communities. For this study, 219 fishing days were carried out in Bahia de Navidad, Jalisco, Mexico. Four gillnets with different mesh sizes (76.2, 88.9, 101.6 and $114.3 \mathrm{~mm}$ ) were used for the fishing operations, from April 1994 to March 1995 and from January 1998 to December 2000. A total of 26126 organisms weighting $11680 \mathrm{~kg}$ were caught. One hundred and eighty three species belonging to 57 families and 19 orders were identified. Ten species accumulated more than $60 \%$ of the total abundance and biomass, the remaining species (173) individually contributed with less than $2 \%$ of the total abundance and biomass. The most important species in the catch were Microlepidotus brevipinnis, Caranx caballus, Haemulon flaviguttatum, Scomberomorus sierra, C. caninus, C. sexfasciatus, Lutjanus guttatus and L. argentiventris. The catch per unit of effort showed a large variation during the study, both in number and biomass. On average, 110 fishes and $48.5 \mathrm{~kg}$ fishing day ${ }^{-1}$ were caught. The maximum values were recorded during January and October 1998 ( 250 fishes and $100 \mathrm{~kg}$ fishing day $^{-1}$ ), and the minimum values were recorded during September and November 1994 ( $25 \mathrm{org}$. and $10 \mathrm{~kg}$ fishing day $\left.{ }^{-1}\right)$. The total abundance and biomass was lower during the $1994-95$ period $(F=6.16,8.32, P<0.05)$. There were statistically significant differences among the annual catch from each gillnet. All the environmental changes caused by the ENSO event had ecological and economic effects that can be rated from moderate to severe. Rev. Biol. Trop. 56 (1): 133-152. Epub 2008 March 31.
\end{abstract}

Key words: Mexico, Jalisco, fish species composition, small-scale fisheries, El Niño southern oscillation, catch per unit of effort.

In the tropical and subtropical coastal zone highly diverse fish communities occur (Longhurst and Pauly 1987). Such communities are integrated by different organisms, like pelagic fishes and organisms associated to the bottom or shelters like demersal fishes (Allen and Robertson 1994), involving complex and unstable interrelations between fish fauna of the environment (Auster 1988).
It is important to study the small scale fisheries exploiting these communities: in the central Mexican Pacific, these fisheries are characterized by the use of several fishing gears and the exploitation of several species. Gillnets are the most commonly used fishing gears in these fisheries. The nets are frequently used on soft bottom and the fishing effort is focused on demersal and benthic fishes. The 
gillnets are constructed with meshes of a wide range of sizes, giving rise to catches of high species richness and causing a complex pattern of differential fishing mortality in exploited stocks (Rojo-Vázquez et al. 1999, 2001).

The reliable management of the multispecies fisheries requires understanding the structure and dynamics of the fish community, from which (1) ecological and fishery implications of the exploitation strategies could be foreseen (Brander 1988, Sainsbury 1982), and (2) the undesirable changes in the specific composition could be prevented while the desirable ones are shown (Pauly and Murphy 1982, Sherman and Alexander 1986)

Since the end of the 70's, great climatic and oceanographic changes have happened in the Pacific Ocean, which have affected the marine ecosystem (Brodeur and Ware 1995, Francis and Hare 1994, Hollowed and Wooster 1995). As a result, one of the most important changes observed in the system is in the catch composition from several fisheries.

The environment from the tropical Eastern Pacific shows seasonal and interannual changes and at higher scales (decadal and climatic change). The interannual variability of the oceanographic conditions is relatively strong in the Equatorial Eastern Pacific due to the natural cycle of the ocean-atmosphere system called El Niño Southern Oscillation (ENSO), which occurs at irregular time intervals (2 to 7 years) and lasting 12-18 months. The ENSO is an irregular fluctuation that involves all the Tropical Pacific Ocean and the global atmosphere (Philander 1999).

During the last 50 years there have been 12 El Niño events, being the most intense events during 1982-83 and 1997-98 (Trenberth 1997), the latest called "the climatic event of the century" (McPhaden 1999), because it was considered the largest and hottest from the latest 100 years (Changnon 2000). In contrast, during the period 1980-1998, there were only three La Niña episodes during 1988-89, 1995-96 and 1998-99 (Magaña and Morales 1999). A generalization about the ENSO effects on higher organisms was made by Sharp (1992): examining the facts closely, it has been shown that the effects from individual El Niño events can be devastating, but, in a short time period, most of the effects disappear.

This paper analyses the changes in the fish species composition and the changes in the catch per unit of effort from the artisanal gillnet fishery in the Mexican central Pacific, comparing results before, during and after the 1997-98 ENSO event, in order to test the hypothesis that these anomalous events promote changes in the fish species composition of the catches in tropical fish communities.

\section{MATERIALS AND METHODS}

Study site: the study area is located in Bahia de Navidad, Jalisco Mexico, in the coastal zone of the Mexican central Pacific $\left(19^{\circ} 10^{\prime} 30^{\prime \prime}\right.$ and $19^{\circ} 12^{\prime} 50^{\prime \prime} \mathrm{N}$ and $104^{\circ} 42^{\prime}$ $45^{\prime \prime}$ and $\left.104^{\circ} 41^{\prime} 30^{\prime \prime} \mathrm{W}\right)$. The coastline of the bay is characterized by sandy beaches alternating with rocky shores and cliffs, with different kinds of substratum like, e.g. rocky bottom (Caleta Cuastecomatito and Punta Corrales), soft bottom (Bahía de Cuastecomates and Bahia de Melaque) and soft bottom with small rocks. The last is the most frequently used by fishermen in gillnet fishing operations.

Fishing operations: during 47 months, five consecutive days each month, in average, experimental fishing operations were made, from April 1994 through March 1995, and from January 1998 through December 2000. Four gillnets with different mesh size (76.2, $88.9,101.6$ and $114.3 \mathrm{~mm}$ ) were used, except during 1994-95, when the $101.6 \mathrm{~mm}$ mesh size was not used. These gillnets were designed to operate on the bottom and were placed over depth ranges of 7 to $12 \mathrm{~m}$. The fishing operations were carried out during the night, and the catch was separated according the gillnet type. All fish caught were measured as total length $(\mathrm{TL} \mathrm{cm})$ and total weight $(\mathrm{TW} \mathrm{g})$. 
Relative Importance Index (RII): the index was used to show the most important species in the catch, which uses a relative measure of each species for the abundance ( $\%$ of individuals), biomass ( $\% \mathrm{~kg})$ and frequency ( $\%$ of samples):

$$
\mathbf{R I I}=\% \mathrm{~N}+\% \mathrm{P}+\% \mathrm{~F}
$$

Where, $\% \boldsymbol{N}$ is the relative abundance of each specie, $\boldsymbol{\% P}$ is the relative biomass and $\boldsymbol{\%} \boldsymbol{F}$ is the relative frequency in the samples (De la Cruz-Agüero 1994).

Dominance: dominance patterns were analyzed using several kinds of curves like dominance plot, k-dominance curves and geometric class curves, which enable to extract information about the species relative abundance, without reducing that information to a simple index (Clarke and Warwick 1994).

Catch per unit of effort analysis. (CPUE): to analyze the variation of the CPUE, the unit of effort used was a fishing day, where the same number and type of gillnets were used, giving number of fish and kilograms per fishing day. The monthly abundance or biomass values are given in all cases as the cumulative catch of the five fishing days. Differences in CPUE among years for the total catch, in number and kilograms, the catch of each kind of gillnet and the catch for the five most important species were tested using a one-way ANOVA. Abundance and biomass data were transformed to $\log (\mathrm{x}+1)$. When significant differences were found, Tukey's test (Zar 1999) was used to conduct multiples comparisons. Prior to each analysis, data were checked for homogeneity of variances using Cochran's test (Zar 1999).

\section{RESULTS}

Fish species composition: during this study 219 fishing days were carried out. A total of 26,126 organisms and $11,680 \mathrm{~kg}$ were caught. One hundred and eighty three species belonging to 57 families and 19 orders were identified. The families with the largest number of species were Carangidae (25), Haemulidae (17), Sciaenidae (16) and Serranidae (10).

From the 183 species caught, ten species accumulated more than $60 \%$ of the total abundance and biomass, the remaining species (173) individually contributed with less than $2 \%$ of the total abundance and biomass (Fig. 1). The most important species in the catch, according to the RII were Microlepidotus brevipinnis (138\%), Caranx caballus (114\%), Haemulon flaviguttatum and Scomberomorus sierra $(105 \%)$, C. caninus (104\%), C. sexfasciatus (104\%), Lutjanus guttatus (102\%) and L. argentiventris (101\%) (Table 1).

The geometric classes curves show that both, totally and within years, a marked dominance pattern was present, and that a great number of species (up to $75 \%$ ) could be considered as rare or occasional, because of the low numbers caught (less then 30 organisms) (Fig. 2).

Period 1994-1995: during this year 4,191 organisms weighting $1,735 \mathrm{~kg}$, were caught, belonging to 75 fish species. According to RII values, the most important species were $M$. brevipinnis (148\%), C. caballus (118\%), H. flaviguttatum (108\%), A. interruptus (105\%), C. sexfasciatus (104\%), Pomadasys branickii and Lutjanus guttatus (103\%) and Scomberomorus sierra (101\%) (Table 2). The ten most important species accumulated $75 \%$ of the total abundance and $70 \%$ of the total biomass. Only six species $(8 \%)$ were caught during 12 months, and 40 species $(53 \%)$ were caught during three months or less (Fig. 2).

Period 1998: during this period 6,844 organisms weighting $3,231 \mathrm{~kg}$ and belonging to 130 fish species were caught. Only ten species $(7.5 \%)$ accumulated almost $75 \%$ of the total abundance and biomass (Fig. 2). In this case two species show a high dominance, M. brevipinnis and C. caninus; only $10 \%$ of the species (14) were caught during 10 to 12 months, while 57\% (74 species) were caught 


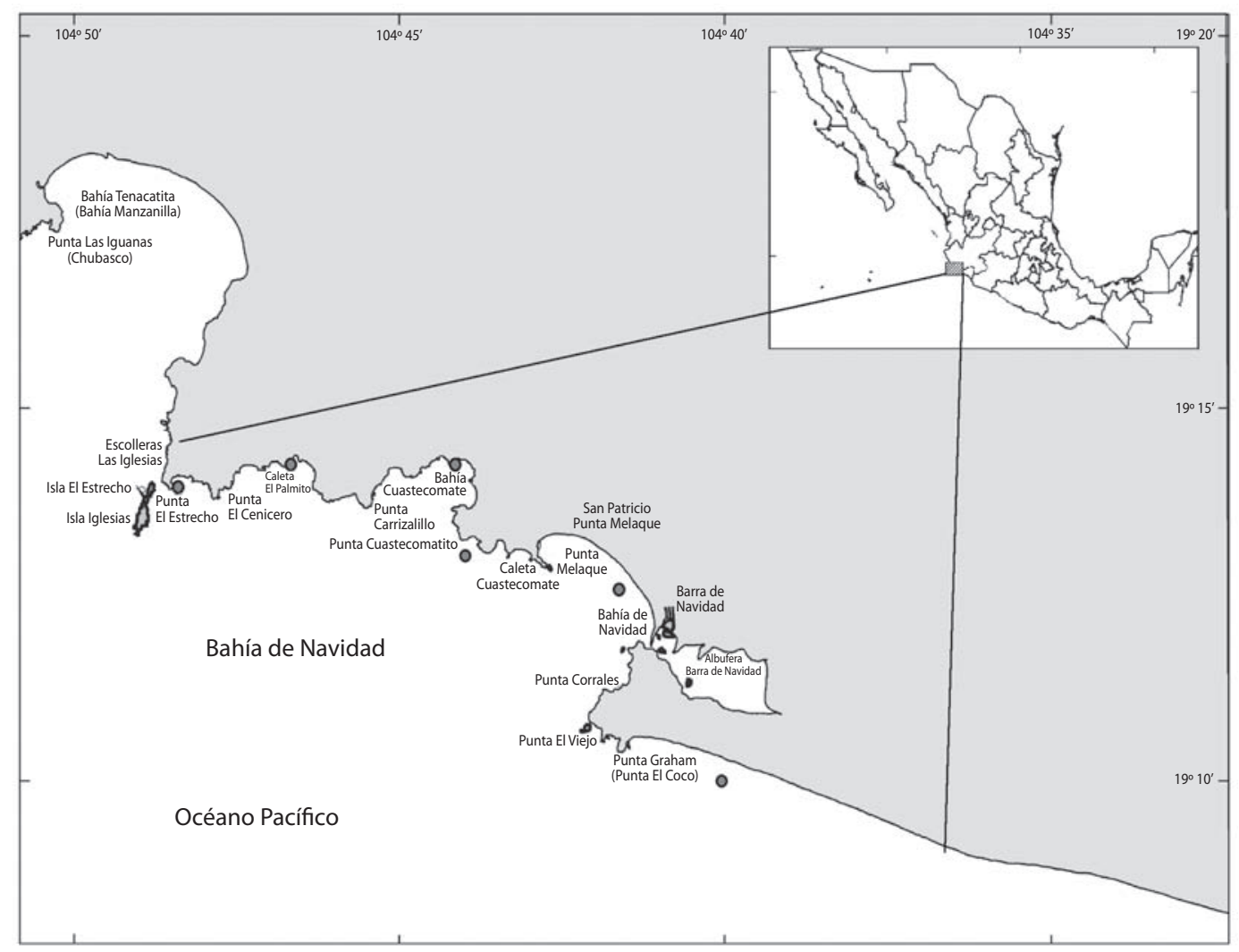

Fig. 1. Study area: Bahía de Navidad, Jalisco, México.

during three or less months. The most important species, according to the RII values were M. brevipinnis (147\%), C. caninus (135\%), C. caballus (113\%), Kyphosus analogus y $S$. sierra (108\%), C. sexfasciatus (107\%), and K. elegans (105\%) (Table 2).

Period 1999: during this year 8,869 organisms and $3,814.8 \mathrm{~kg}$ were caught, belonging to 141 fish species. Ten species accumulated almost $55 \%$ of the total abundance and $50 \%$ of biomass (Fig. 2). Only 20 species (14\%) were caught during 10 to 12 months, and $51 \%$ (72 species) were caught during three months or less. The most important species were $M$. brevipinnis (131\%), C. caballus (112\%), S. sierra $(105 \%)$, C. sexfasciatus (103\%), H. flaviguttatum y H. scudderi (101\%) and L. guttatus (100\%) (Table 2).
Period 2000: in this year 6,120 organisms weighting $2,895.5 \mathrm{~kg}$ and belonging to 128 fish species were caught. The ten most important species accumulated $65 \%$ of the total abundance and $60 \%$ of the biomass (Fig. 2). Only 19 species (14\%) were caught during 10 or 11 months, while 69 species (53\%) were caught during three months or less. The most important species were M. brevipinnis (131\%), C. caballus (116\%), H. flaviguttatum y L. guttatus $(114 \%)$, Umbrina xanti (111\%), S. sierra (108\%), and $L$. argentiventris (105\%) (Table 2).

Abundance and Biomass variation: the Catch Per Unit of Effort (CPUE: \# organisms and $\mathrm{kg}$ per fishing day) showed great variation during the study, both in number and in biomass, although both patterns were very similar. On average, 110 organisms and $48.5 \mathrm{~kg}$ 
TABLE 1

Values of the Relative Importance Index for the 30 most important species of fishes during all the period of study

\begin{tabular}{|c|c|c|c|c|c|c|c|}
\hline 183 species & (\# org) & $(\%)$ & $(\mathrm{kg})$ & $(\%)$ & (months) & $(\%)$ & Index \\
\hline Microlepidotus brevipinnis & 5926 & 22.68 & 1825.17 & 15.63 & 47 & 100.00 & 138.31 \\
\hline Caranx caballus & 1830 & 7.00 & 873.59 & 7.48 & 47 & 100.00 & 114.48 \\
\hline Haemulon flaviguttatum & 1483 & 5.68 & 504.66 & 4.32 & 45 & 95.74 & 105.74 \\
\hline Scomberomorus sierra & 718 & 2.75 & 589.55 & 5.05 & 46 & 97.87 & 105.67 \\
\hline Caranx caninus & 2112 & 8.08 & 940.56 & 8.05 & 42 & 89.36 & 105.50 \\
\hline Caranx sexfasciatus & 507 & 1.94 & 279.69 & 2.39 & 47 & 100.00 & 104.34 \\
\hline Lutjanus guttatus & 1398 & 5.35 & 629.46 & 5.39 & 43 & 91.49 & 102.23 \\
\hline Lutjanus argentiventris & 660 & 2.53 & 326.45 & 2.79 & 45 & 95.74 & 101.07 \\
\hline Anisotremus interruptus & 423 & 1.62 & 227.30 & 1.95 & 44 & 93.62 & 97.18 \\
\hline Elops affinis & 350 & 1.34 & 155.89 & 1.33 & 44 & 93.62 & 96.29 \\
\hline Trachinothus rhodopus & 1165 & 4.46 & 312.05 & 2.67 & 39 & 82.98 & 90.11 \\
\hline Mulloidichthys dentatus & 374 & 1.43 & 134.30 & 1.15 & 41 & 87.23 & 89.82 \\
\hline Epinephelus labriformes & 218 & 0.83 & 99.70 & 0.85 & 41 & 87.23 & 88.92 \\
\hline Haemulon sexphasciatus & 224 & 0.86 & 93.67 & 0.80 & 40 & 85.11 & 86.77 \\
\hline Kyphosus analogus & 669 & 2.56 & 347.41 & 2.97 & 37 & 78.72 & 84.26 \\
\hline Lutjanus inermis & 143 & 0.55 & 29.23 & 0.25 & 36 & 76.60 & 77.39 \\
\hline Sectator ocyurus & 234 & 0.90 & 276.91 & 2.37 & 31 & 65.96 & 69.22 \\
\hline Katsuwomus pelamis & 262 & 1.00 & 307.57 & 2.63 & 30 & 63.83 & 67.47 \\
\hline Kyphosus elegans & 308 & 1.18 & 281.73 & 2.41 & 30 & 63.83 & 67.42 \\
\hline Tylosurus acus pacificus & 50 & 0.19 & 115.00 & 0.98 & 30 & 63.83 & 65.01 \\
\hline Haemulon maculicauda & 132 & 0.51 & 27.62 & 0.24 & 30 & 63.83 & 64.57 \\
\hline Gerres cinereus & 110 & 0.42 & 35.22 & 0.30 & 29 & 61.70 & 62.42 \\
\hline Haemulopsis elongatus & 263 & 1.01 & 146.15 & 1.25 & 28 & 59.57 & 61.83 \\
\hline Haemulon scudderi & 153 & 0.59 & 50.08 & 0.43 & 27 & 57.45 & 58.46 \\
\hline Nematistius pectoralis & 208 & 0.80 & 216.03 & 1.85 & 26 & 55.32 & 57.96 \\
\hline Umbrina xanti & 731 & 2.80 & 219.90 & 1.88 & 25 & 53.19 & 57.87 \\
\hline Selene peruviana & 394 & 1.51 & 42.43 & 0.36 & 26 & 55.32 & 57.19 \\
\hline Lutjanus novenfasciatus & 61 & 0.23 & 58.70 & 0.50 & 26 & 55.32 & 56.06 \\
\hline Myripristris leiognathus & 71 & 0.27 & 6.40 & 0.05 & 24 & 51.06 & 51.39 \\
\hline Caranx vinctus & 226 & 0.87 & 74.86 & 0.64 & 23 & 48.94 & 50.44 \\
\hline 153 species & 4723 & 18.08 & 2452.82 & 21.00 & & & \\
\hline
\end{tabular}



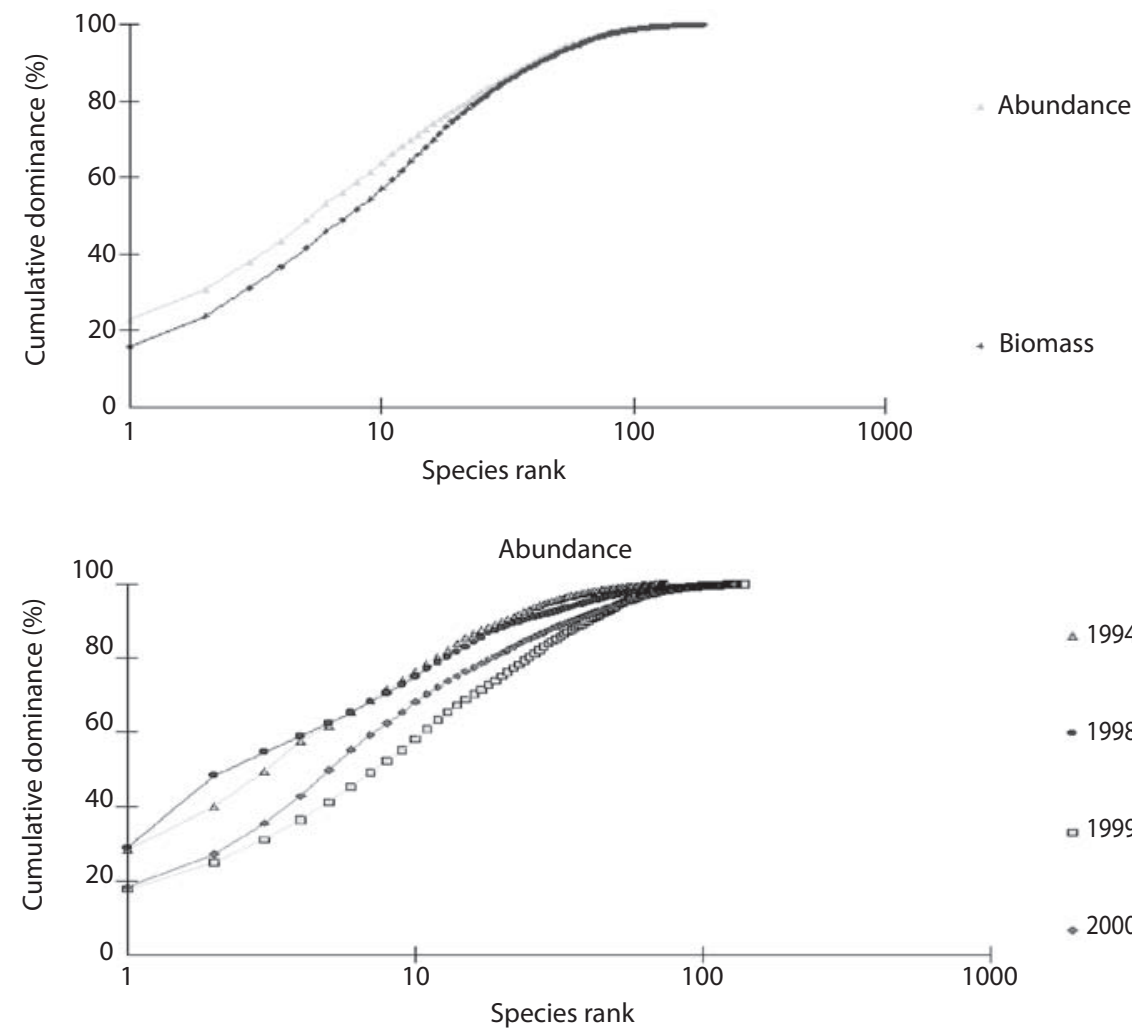

- 1999

. 2000

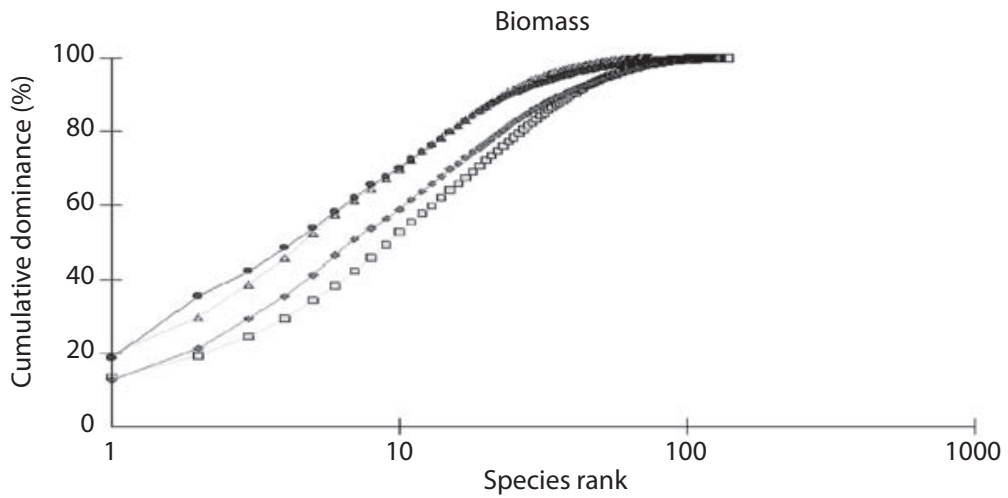

A 1994-95

- 1998

- 1999

- 2000

Fig. 2.- Total and yearly k-dominance (abundance and biomass) curves for the catch of the gillnet fishery from Jalisco, Mexico. 
TABLE 2

Values of the Relative Importance Index for the most important species of each year

\begin{tabular}{|c|c|c|c|c|c|c|c|}
\hline & Abundance & $\begin{array}{c}\text { Relative } \\
\text { importance }\end{array}$ & Biomass & $\begin{array}{c}\text { Relative } \\
\text { importance }\end{array}$ & Frequency & $\begin{array}{c}\text { Relative } \\
\text { importance }\end{array}$ & $\begin{array}{l}\text { Relative } \\
\text { importance }\end{array}$ \\
\hline PERIOD 1994-95 & (\# org) & $(\%)$ & $(\mathrm{kg})$ & $(\%)$ & (months) & $(\%)$ & Index \\
\hline Microlepidotus brevipinnis & 1195 & 28.51 & 338.61 & 19.51 & 12 & 100.00 & 148.02 \\
\hline Caranx caballus & 336 & 8.02 & 178.20 & 10.27 & 12 & 100.00 & 118.28 \\
\hline Haemulon flaviguttatum & 401 & 9.57 & 122.45 & 7.05 & 11 & 91.67 & 108.29 \\
\hline Anisotremus interruptus & 94 & 2.24 & 53.89 & 3.10 & 12 & 100.00 & 105.35 \\
\hline Caranx sexfasciatus & 72 & 1.72 & 42.72 & 2.46 & 12 & 100.00 & 104.18 \\
\hline Pomadasys branickii & 96 & 2.29 & 28.55 & 1.64 & 12 & 100.00 & 103.94 \\
\hline Lutjanus guttatus & 475 & 11.33 & 154.21 & 8.88 & 10 & 83.33 & 103.55 \\
\hline Scomberomorus sierra & 138 & 3.29 & 118.46 & 6.82 & 11 & 91.67 & 101.78 \\
\hline Lutjanus inermis & 27 & 0.64 & 5.06 & 0.29 & 12 & 100.00 & 100.94 \\
\hline Lutjanus argentiventris & 149 & 3.56 & 68.53 & 3.95 & 11 & 91.67 & 99.17 \\
\hline 65 species & 1208 & 28.82 & 625.15 & 36.02 & & & \\
\hline \multicolumn{8}{|l|}{ PERIOD 1998} \\
\hline Microlepidotus brevipinnis & 2015 & 28.98 & 603.91 & 18.66 & 12 & 100.00 & 147.65 \\
\hline Caranx caninus & 1333 & 19.17 & 543.73 & 16.80 & 12 & 100.00 & 135.98 \\
\hline Caranx caballus & 440 & 6.33 & 217.70 & 6.73 & 12 & 100.00 & 113.06 \\
\hline Caranx sexfasciatus & 237 & 3.41 & 116.21 & 3.59 & 12 & 100.00 & 107.00 \\
\hline Scomberomorus sierra & 202 & 2.91 & 172.04 & 5.32 & 12 & 100.00 & 108.22 \\
\hline Kyphosus analogus & 303 & 4.36 & 140.85 & 4.35 & 12 & 100.00 & 108.71 \\
\hline Kyphosus elegans & 140 & 2.01 & 120.74 & 3.73 & 12 & 100.00 & 105.74 \\
\hline Lutjanus argentiventris & 85 & 1.22 & 42.41 & 1.31 & 12 & 100.00 & 102.53 \\
\hline Elops affinis & 174 & 2.50 & 61.99 & 1.92 & 12 & 100.00 & 104.42 \\
\hline Haemulon flaviguttatum & 92 & 1.32 & 34.76 & 1.07 & 12 & 100.00 & 102.40 \\
\hline 118 species & 1927 & 27.78 & 1179.57 & 36.52 & & & \\
\hline \multicolumn{8}{|l|}{ PERIOD 1999} \\
\hline Microlepidotus brevipinnis & 1587 & 17.89 & 512.07 & 13.42 & 12 & 100.00 & 131.32 \\
\hline Caranx caballus & 546 & 6.16 & 229.16 & 6.01 & 12 & 100.00 & 112.16 \\
\hline Scomberomorus sierra & 185 & 2.09 & 134.92 & 3.54 & 12 & 100.00 & 105.62 \\
\hline Caranx sexfasciatus & 120 & 1.35 & 78.07 & 2.05 & 12 & 100.00 & 103.40 \\
\hline Haemulon flaviguttatum & 452 & 5.10 & 186.77 & 4.90 & 11 & 91.67 & 101.66 \\
\hline Haemulon scudderi & 79 & 0.89 & 24.88 & 0.65 & 12 & 100.00 & 101.54 \\
\hline Lutjanus guttatus & 343 & 3.87 & 188.29 & 4.94 & 11 & 91.67 & 100.47 \\
\hline Kyphosus analogus & 277 & 3.12 & 153.60 & 4.03 & 11 & 91.67 & 98.82 \\
\hline Lutjanus argentiventris & 252 & 2.84 & 129.00 & 3.38 & 11 & 91.67 & 97.89 \\
\hline Anisotremus interruptus & 112 & 1.26 & 60.94 & 1.60 & 11 & 91.67 & 94.53 \\
\hline 131 species & 4916 & 55.43 & 2117.13 & 55.49 & & & \\
\hline
\end{tabular}


TABLE 2 (Continued...)

Values of the Relative Importance Index for the most important species of each year

$$
\text { Abundance } \begin{gathered}
\text { Relative } \\
\text { importance }
\end{gathered} \text { Biomass } \begin{gathered}
\text { Relative } \\
\text { importance }
\end{gathered} \text { Frequency } \begin{gathered}
\text { Relative } \\
\text { importance }
\end{gathered} \begin{gathered}
\text { Relative } \\
\text { importance }
\end{gathered}
$$

PERIOD 2000

$\begin{array}{lccccccc}\text { MicrolepIdotus brevipinnis } & 1129 & 18.45 & 370.57 & 12.80 & 11 & 100.00 & 131.25 \\ \text { Caranx caballus } & 508 & 8.30 & 248.53 & 8.58 & 11 & 100.00 & 116.88 \\ \text { Lutjanus guttatus } & 429 & 7.01 & 229.40 & 7.92 & 11 & 100.00 & 114.93 \\ \text { Haemulon flaviguttatum } & 538 & 8.79 & 160.68 & 5.55 & 11 & 100.00 & 114.34 \\ \text { Umbrina xanti } & 434 & 7.09 & 121.05 & 4.18 & 11 & 100.00 & 111.27 \\ \text { Scomberomorus sierra } & 193 & 3.15 & 164.15 & 5.67 & 11 & 100.00 & 108.82 \\ \text { Lutjanus argentiventris } & 174 & 2.84 & 86.51 & 2.99 & 11 & 100.00 & 105.83 \\ \text { Mulloidichthys dentatus } & 126 & 2.06 & 44.77 & 1.55 & 11 & 100.00 & 103.60 \\ \text { Caranx sexfasciatus } & 78 & 1.27 & 42.69 & 1.47 & 11 & 100.00 & 102.75 \\ \text { Caranx caninus } & 338 & 5.52 & 175.61 & 6.06 & 10 & 90.91 & 102.50 \\ \text { 118 species } & 2173 & 35.50 & 1251.56 & 43.23 & & & \end{array}$

fishing day ${ }^{-1}$ were caught. The maximum values were recorded during January and October of 1998 (250 organisms and $100 \mathrm{~kg}$ fishing day $\left.^{-1}\right)$, and the minimum values were recorded during September and November of 1994 (25 organisms and $10 \mathrm{~kg}$ fishing day $^{-1}$ ) (Fig. 3). The total abundance and biomass were lower during the $1994-95$ period $(F=6.16,8.32$, $P<0.05$ ) (Table 3).

Only for the monthly abundance and biomass of the 1998 period significant statistic differences were found $(F=4.33,3.23, P<0.05)$ (Table 3).

CPUE by type of net: the maximum catch, in number of organisms, was obtained using the $76.2 \mathrm{~mm}$ gillnet mesh size that caught 11,402 fishes (44\% of the total), 51 organisms fishing day $^{-1}$ on average, followed the $88.9 \mathrm{~mm}$ net that caught 8,808 organisms (34\%) with 33 org. fishing day $^{-1}$ on average, the $101.6 \mathrm{~mm}$ net caught 3,458 organisms $(13 \%)$ and 20 fishes fishing day $^{-1}$, and finally, the $114.3 \mathrm{~mm}$ gillnet that caught 2,464 organisms (9\%) and 11 org. fishing day $^{-1}$. In relation to the biomass, the $88.9 \mathrm{~mm}$ gillnet caught 3,706 $\mathrm{kg}(32 \%)$ with $17 \mathrm{~kg}$ fishing day $^{-1}$, followed by the $76.2 \mathrm{~mm}$ net that caught $3,614 \mathrm{~kg}\left(31 \%, 16 \mathrm{~kg}\right.$ fishing day $\left.{ }^{-1}\right)$, the 101.6 mm gillnet caught $2,067 \mathrm{~kg}(18 \%)$ and, finally, the $114.3 \mathrm{~mm}$ caught $2,294 \mathrm{~kg}(20 \%)$, with 10 $\mathrm{kg}$ fishing day ${ }^{-1}$ on average. The variation of the CPUE in number showed significant difference between the $76.2 \mathrm{~mm}$ gillnet mesh size and the other nets, however such difference was smaller in terms of biomass (Fig. 4).

There were significant statistic variations within the annual catch from each gillnet. The main differences were observed for the catch of the $88.9 \mathrm{~mm}$ mesh size from $1994-95$ respect to 1998 and 1999, and between the catch of the $114.3 \mathrm{~mm}$ mesh size from 1998 respect 1999 (Table 3).

CPUE of the most important species: six species were selected to analyze their CPUE variations, finding a great similarity in their abundance and biomass pattern for all the species selected. However each species showed some seasonal pattern in the different years, and some of them, like Caranx caninus, 

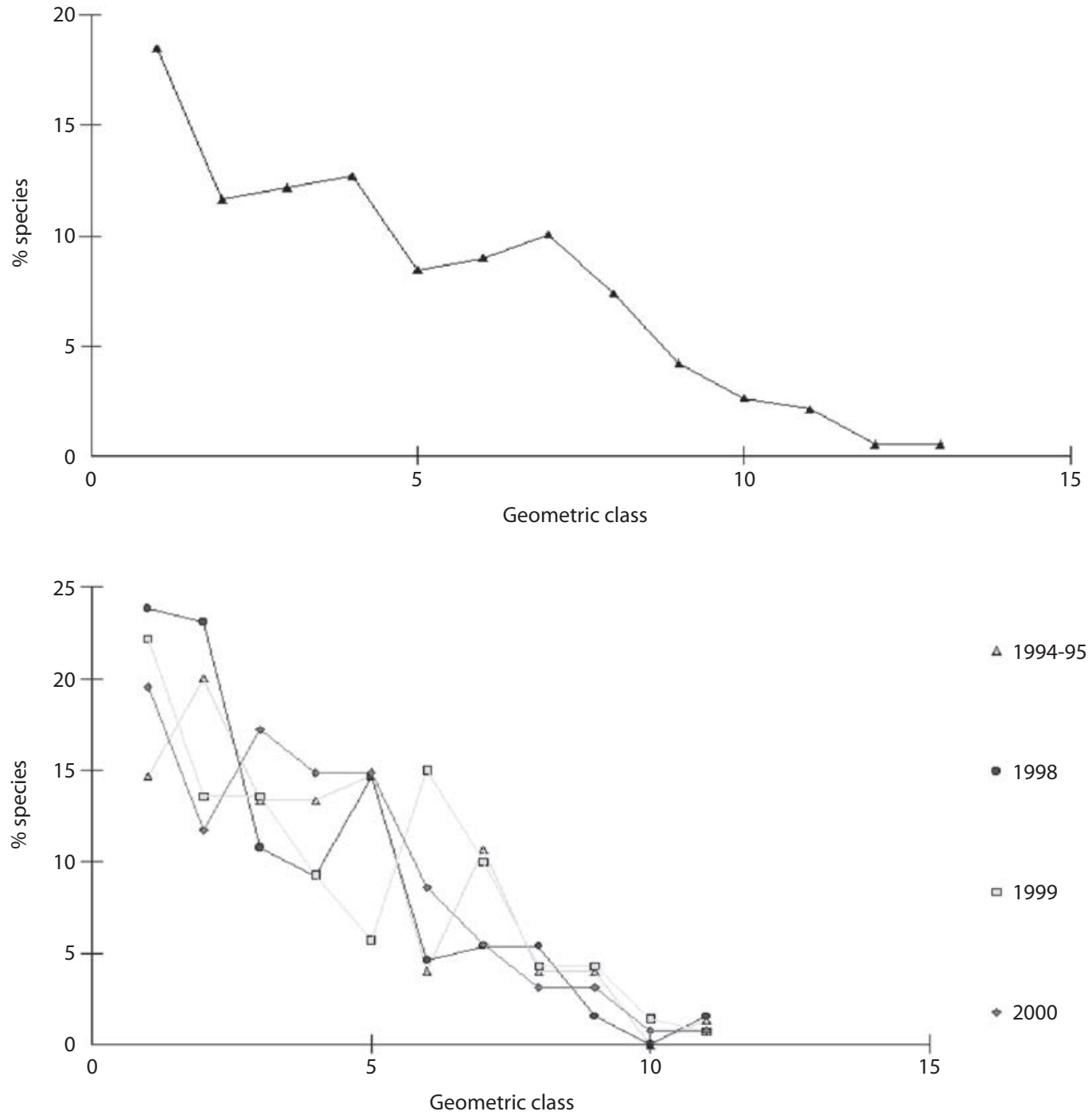

Fig. 3. Total and yearly geometric class curve for the catch of the gillnet fishery from Jalisco, Mexico.

Haemulon flaviguttatum and Lutjanus guttatus show predominance on some specific years (Fig. 5).

Significant statistic differences for the total abundance and biomass of $C$. caninus, $H$. flaviguttatum and L. guttatus were found (Table 3); due to the fluctuating catches of these species during 1998.

\section{DISCUSSION}

Fish species composition: although the topic of the climatic variability has attracted the public's attention in the world during some time, the 1997-98 ENSO events has specifically interested to different sectors of the scientific society. Droughts, forest fires, excessive 
TABLE 3

Results of the Anova of the CPUE for the abundance and biomass

Totals

Total abundance

Total biomass

Abundance 98-00

Biomass 98-00

Abundance 1994-95

Biomass 1994-95

Abundance 1998

Biomass 1998

Abundance 1999

Biomass 1999

Abundance 2000

Biomass 2000

BY KIND OF NET

Abundance 3.0" gillnet

Biomass 3.0" gillnet

Abundance 3.5" gillnet

Biomass 3.5" gillnet

Abundance 4.0" gillnet

Biomass 4.0" gillnet

Abundance 4.5" gillnet

Biomass 4.5" gillnet

BY SPECIES: TOTAL ABUNDANCE

Caranx caballus

Caranx caninus

Haemulon flaviguttatum

Lutjanus guttatus

Microlepidotus brevipinnis

Scomberomorus sierra

BY SPECIES: TOTAL BIOMASS

Caranx caballus

Caranx caninus

Haemulon flaviguttatum

Lutjanus guttatus

Microlepidotus brevipinnis

Scomberomorus sierra
Effect df

3

3

2

2

11

11

11

11

11

11

10

10

3

3

3

3

2

2

3

3

3

3

3

3

3

3

3

3

3

3

3

3
Error df

F

3.952

5.307

1.510

0.880

2.193

1.550

3.424

3.203

0.668

0.441

1.073

2.193

40

.408

1.095

4.662

5.962

3.082

2.934

14.434

9.525

43

\section{3}

0.869

2.575

3.678

0.650

0.534

0.381

43

43

0.766

4.086

3.526

0.636

0.709

0.503 p-level

0.01

0.00

0.24

0.42

0.04

0.17

0.00

0.00

0.76

0.93

0.40

0.31

0.25

0.36

0.01

0.00

0.06

0.07

0.00

0.00

0.46

0.07

0.02

0.59

0.66

0.77

0.52

0.01

0.02

0.60

0.55

0.68 
TABLE 3 (Continued...)

Results of the Anova of the CPUE for the abundance and biomass

Totals

BY SPECIES: ABUNDANCE 1998-00

Caranx caballus

Caranx caninus

Haemulon flaviguttatum

Lutjanus guttatus

Microlepidotus brevipinnis

Scomberomorus sierra

BY SPECIES: BIOMASS 1998-00

Caranx caballus

Caranx caninus

Haemulon flaviguttatum

Lutjanus guttatus

Microlepidotus brevipinnis

Scomberomorus sierra

* shows statistic significance differences
Effect df $\quad$ Error df $\quad$ F $\quad$ p-level

0.347

0.71

2.164

0.13

2

5.096

0.01

3.119

0.06

$2 \quad 32$

0.429

0.65

0.042

0.96

2

32

0.316

0.73

3.002

0.06

2

4.854

0.01

3.581

0.04

0.297

0.74

0.206

0.81

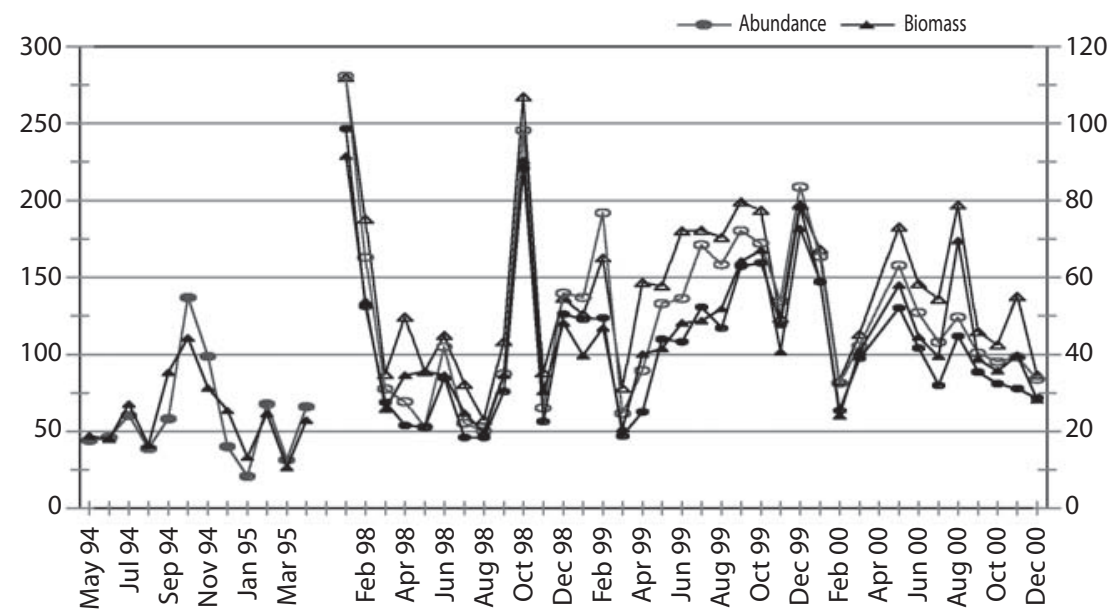

Fig. 4. Variation of the catch per unit effort of the abundance (number of organisms fishing day ${ }^{-1}$ ) and biomass (kg fishing day $^{-1}$ ) from the gillnet fishery from Jalisco, Mexico. Solid lines is the CPUE using three gillnets (3.0", 3.5 and 4.5" mesh size. Dashed lines is the CPUE using the 4.0" gillnet (1998-2000). 

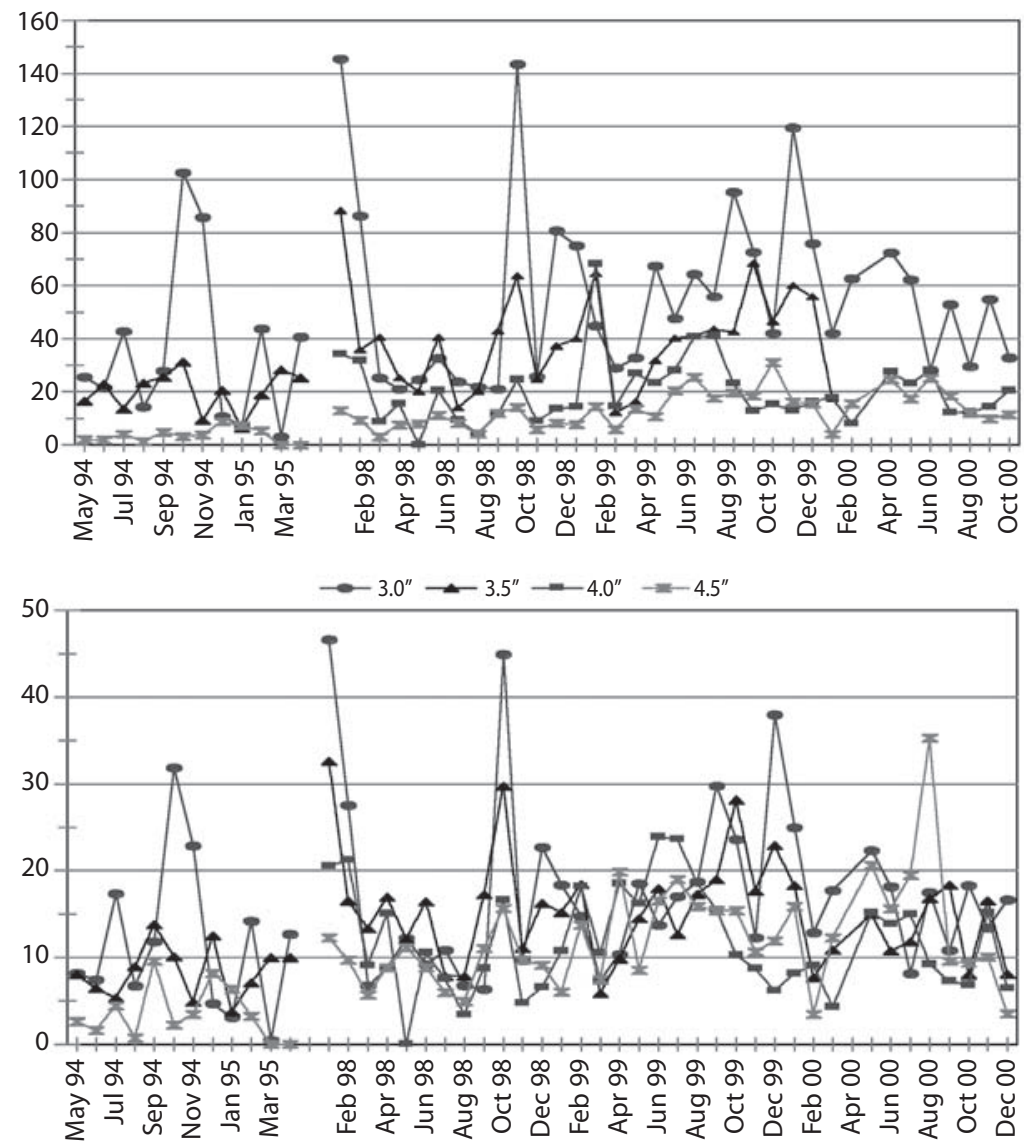

Fig. 5.- Variation of the CPUE by kind of gillnet for abundance (number of organisms fishing day ${ }^{-1}$ ) and biomass (kg fishing day $\left.^{-1}\right)$, from the catch of the gillnet fishery from Jalisco, Mexico.

precipitations, the presence of hurricanes or storms were repeatedly signaled as catastrophes associated to the 1997-98 ENSO events that was particularly intense. In some cases the relation between the El Niño and some of these natural disasters is nonexistent or at least debatable. However, it is clear that this event pointed out the vulnerability of some sectors and activities focused on climatic variability.

The variation in catch composition of gillnet depends, among other factors, on the availability, accessibility and vulnerability of the organisms in relation to the fishing gears (González et al. 1995). However it has been proven that these fishing gears are very efficient in showing the changes in the catch composition (De la Cruz-Aguero et al. 1994, Abitia-Cárdenas et al. 1994, González et al. 1995, Madrid-Vera and Sánchez 1997).

The results reported by Madrid-Vera and Sánchez (1997) show a great similarity with the present study as for the compositional pattern. That is because from their 26 most important species, around $90 \%$ appear within the first 50 species of the present work. Also with that same work there are some differences in the catch seasonality between Bahia de Navidad, Jalisco and Michoacan (Madrid-Vera and Sánchez 1997) due, partly, to the use of a greater diversity of fishing gears. However, in general terms both fisheries present a very similar pattern in the catch, finding that a reduced 
number of species (less than $10 \%$ of the total caught) contribute with more than $50 \%$ to the total catch; being this characteristic pattern of the tropical and subtropical systems (Gaston 2000). Also the composition of the fish fauna in the coastal areas typically suffers marked seasonal changes, which are attributed to the sequential patterns of immigration and emigration of the same species (Hyndes et al. 1999).

The analysis of the relative importance of the fish catch obtained with gillnets from Bahia de Navidad, Jalisco, Mexico, allow us to determine that a reduced number of species contributes in an important way to the capture. The most important species for their contribution in abundance and biomass were M. brevipinnis, C. caninus and C. caballus whose contribution rises to more than $50 \%$ of the total abundance and of $42 \%$ in biomass. In general, the existence of a great number of species with low biomasses per species, is characteristic of the fishing resources in the tropical and subtropical areas (González et al. 1995). This pattern is maintained along the study, a high number of species were caught, but only a few dominate in the community due to their abundance, biomass and frequency in the catches, these few species sustain the effort of the fishery, appearing a great quantity of species with very low abundances and with little frequency, and could be considered as rare or eventual.

According to our results we could verify that, although the ENSO event had a certain effect on the community of fish exploited by the artisanal or small scale fishery, causing the migration of some important species for the fishery, this effect was compensated in turn by the occurrence of other species which may be of less commercial interest. A similar effect is reported, for the same period, for some fisheries in the north of the country, where some species show considerable increases in their catches, while others diminish its abundance, being substituted by new species that enlarged their distribution (Lluch-Cota et al. 1999).

On the other hand it has been observed that the changes in the patterns of presence-absence, abundance, distribution, composition and repro- duction in the populations of fish, due to the El Niño event, are remarkable, causing considerable displacements in these populations, as well as an alterations in the communities (Arntz and Fahrbach 1996). These authors mention this effect for the Peruvian central coast, Chile and the Galápagos, pointing out that most of the autochthonous species disappeared of the shallow area up to $30 \mathrm{~m}$ of depth, which is exploited by the artisanal fishery. Madrid-Vera and Sanchez (1997) report a similar behavior in the fish communities exploited by the artisanal fishery from Michoacan, Mexico.

This seasonal change in the fish species composition of the capture from multispecies fisheries has been observed both, in tropical and temperate areas (Harris and Poiner 1991). Fishing effort (Harris and Poiner 1991), habitat stability (Vanderklift and Jacoby 2003), changes in the recruitment (Gobert 2000) and some interannual global processes (Madrid-Vera and Sanchez 1997) have been mentioned as some of the main causes of the alteration of the fish community. Differences in the fish assemblage among sites that are separated by short distances also have been reported, even though the differences can vary from year to year (Parrish 1989, Loneragan and Potter 1999).

Although the number and the type of species were different during the four years analyzed, there is a coincidence when finding a very similar pattern in their composition, where some species appear throughout the year (20 species) and they could be considered as residents in the area, other species appear in a seasonal way and are captured during five to eight months (around 30 species), and many species that can be considered as rare or eventual (up to 80 species), which appear in the catch during three months or less. However it is important to remark that, from the 20 most important species of each year, considered as residents, around $60 \%$ coincide in every year.

Considering that any extreme perturbation present in the system would affect, in principle, the resident species, some changes are observed in this group of species (Table 2); finding that some species like C. caninus, C. sexfasciatus, 
K. pelamis, E. affinis, even M. brevipinnis, seemed positively affected for the conditions that prevailed during the period 1998, during which the biggest anomalies caused by the El Niño-La Niña event occurred, when these species increased its presence considerably in the catch during that period, compared the previous normal period (1994-95). On the other hand in some species a reverse effect was observed, as H. flaviguttatum, L. guttatus, L. argentiventris, T. rhodopus, which diminished in the captures, specifically during 1998 and were more abundant in the catch before, and after, this year; finally, there were some species that didn't show considerable changes during the ENSO event as C. caballus, S. mountain, A. interruptus, H. sexfasciatus.

Some species of the family Carangidae and Scombridae, like $K$. pelamis have been known that live far from the coast under normal conditions, but during the El Niño conditions, they migrate with the masses of water towards the coast, becoming more vulnerable to the fishery (Arntz and Fahrbach 1996). In the present study it was found that some species of the family Carangidae, as well as $K$. pelamis presented a similar behavior, since during a normal period (prior to the event), Rojo-Vazquez (1997) and Aguilar-Palomino et al. (2001) registered a low relative importance and low frequency, however, during the ENSO event they became important due to its higher abundance and biomass in the area, appearing practically during the whole period.

Lehodey et al. (1997), reported that $K$. pelamis is characterized to inhabit areas of low rate primary production, as found in the warmest Western Pacific, observing that during the formation of the "hot reservoir", characteristic of the ENSO event, this provides a habitat that can sustain the population of this species, resulting in an apparent spatial change in the population of $K$. pelamis that is bound to the great displacement of the warm water that happens during the ENSO events.

Also Seckel and Waldron (1960) reported that $K$. pelamis, from Hawaiian waters, had bigger captures when influence of waters associated to the current of California existed, characterized by low salinities $(34.7 \% \mathrm{o})$, while when there is influence of waters from Northwestern Pacific with more salinity $(35.0 \% \mathrm{o})$ the captures fell notably.

Variation of the abundance: variations in the abundance and biomass of coastal fishes show significant differences among the different years, as well as specifically among the months of 1998 (Fig. 6, Table 3). Finding that very few species had influence on this variation of the total catch. Great deviations are observed in the catch, being the main ones those observed during the first and latest months of 1998, due to the presence of some species that were favored with the climatic changes observed in the area.

The El Niño period, (January to May of 1998) produced a heating in the "normal cold season", while the period La Niña (June to December of 1998) caused the intrusion of cold water during the "normal warm season", which allowed the occurrence of the species before mentioned in a non normal season (GodinezDominguez et al. 2000). That is why the habitat variability has been considered as one of the factors that most severely affect the species composition of the capture (Connell 1978).

Seasonal changes in the catch can be more related with the California Current (Madrid-Vera and Sánchez 1997), besides the event ENSO that was presented in the area during 1997-98. Specifically for some of the most important species the catch per unit effort data showed that the fluctuations in abundance can be related to the climatic periods and the characteristics of the life cycle of each species. For example, $M$. brevipinnis was the most important species in the fishery, being present in $100 \%$ of the samples; this species shows two peaks of abundance, one during the summer months, and another during the winter months. In summer, according to size, most are juvenile fishes, while during winter they are mostly mature individuals that come to the coast to spawn.

The only anomaly in the capture of this species was during the first months of 1998 

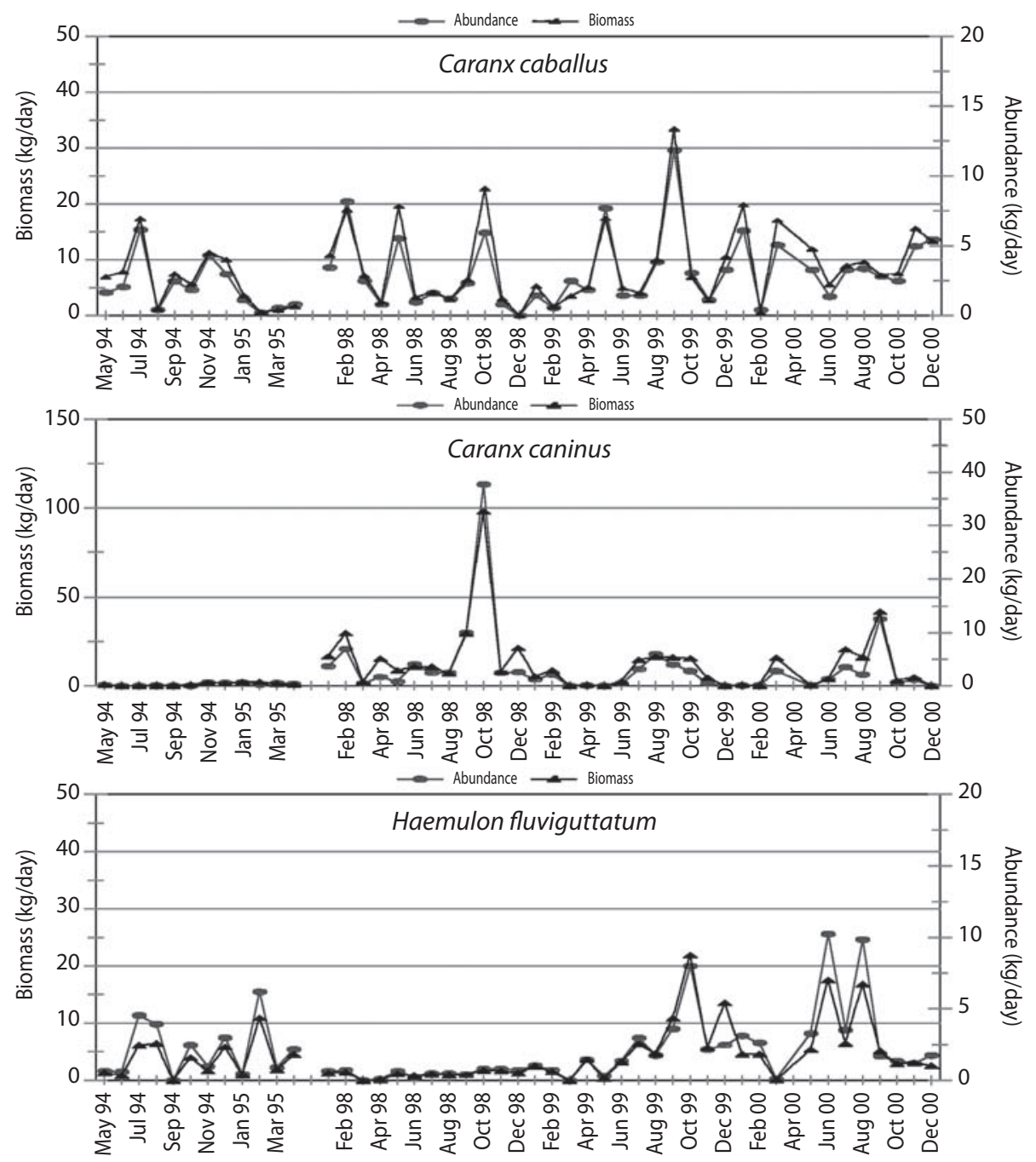

Fig. 6. Variation of the CPUE in abundance and biomass for the most important species. (Continue on next page ...)

when a considerable increase in its abundance with respect to the other months, took place while it practically disappeared during the summer months. C. caninus was the second more abundant species in the capture, present in 42 of 47 months, this species was characterized by some abundance peaks during September and October, benefitting in a notorious way during those same months of 1998.

This behavior for $C$. caninus had already been observed by Madrid-Vera and Sanchez
(1997) in whose study this species was the sixth most important, and it was related to the influence of the Current of California. L. guttatus, occupies the fifth place in abundance and it appeared in 43 of 47 months, it was the most important species in the artisanal fishery from the Coast of Michoacan (Madrid-Vera and Sanchez 1997), and practically it disappeared during the period 1998. For the species $H$. flaviguttatum the most notorious change was present in its abundance, disappearing 

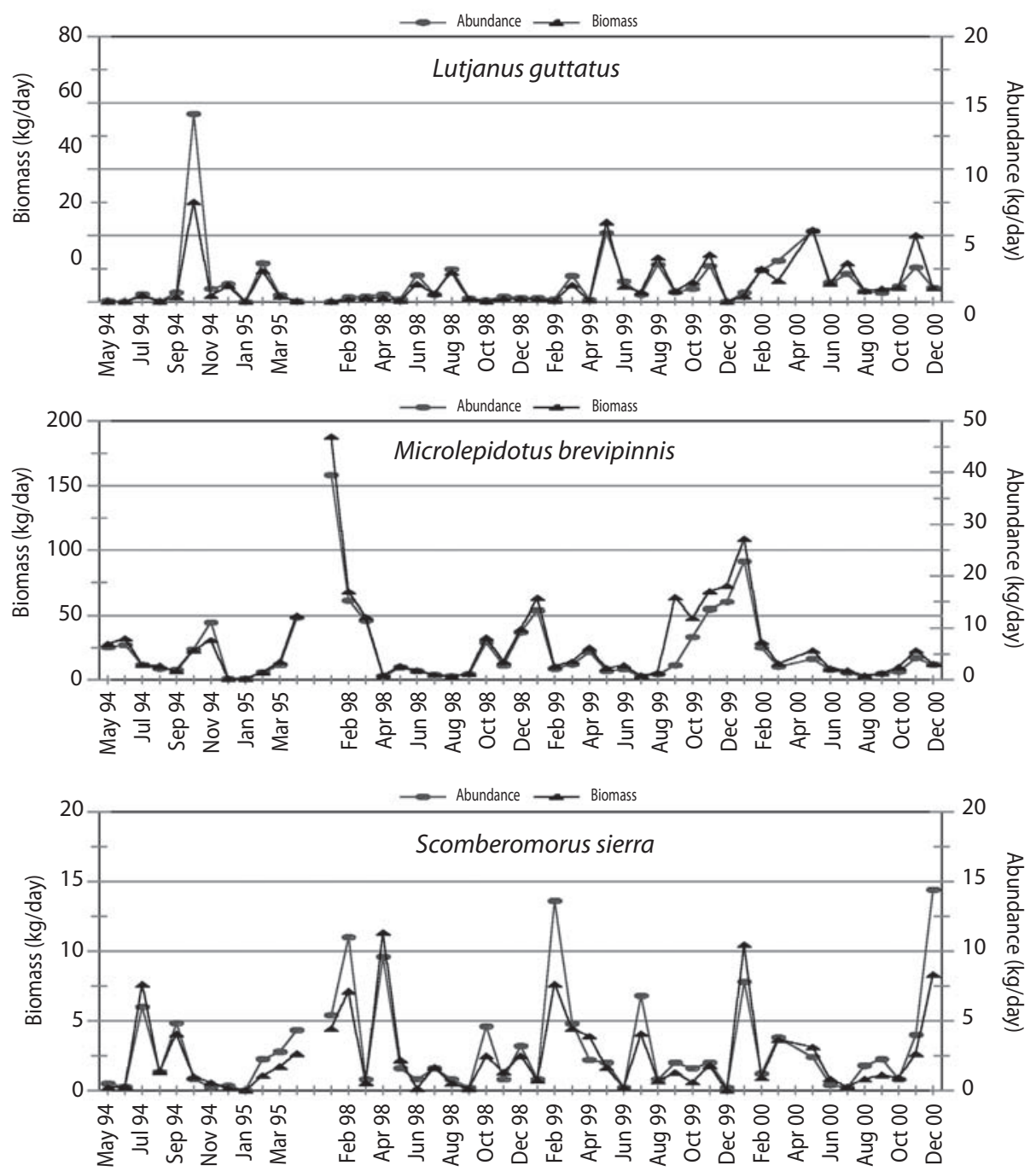

Fig. 6. Continued. Variation of the CPUE in abundance and biomass for the most important species.

almost completely, during the period of 1998, and reappearing in the following years with similar catch levels to those of the normal year (1994-95); this species had previously been reported as characteristic of periods with $\mathrm{La}$ Niña conditions, in the study by Madrid-Vera and Sanchez (1997), $250 \mathrm{~km}$ to the south of the present study.

It is necessary to point out the difference in the number of organisms caught by each one of the used gillnets, being notably bigger the catch obtained by the gillnet of $76.2 \mathrm{~mm}$ of mesh size, followed by the $88.9 \mathrm{~mm}$ gillnet. As expected, smaller differences were found in biomass. These differences in the catches of the smaller mesh sizes compared to the bigger ones should be due mainly to that of the most conspicuous characteristics of the fish communities from coastal areas that is, the abundance of juvenile fishes, and for this reason these areas have been considered as nursery areas (Lindeman and Snyder 1999). 
The effect of impoverishment of the habitat during El Niño event is well-known (Chavez et al. 1999), and many changes in the recruitment of some populations have been attributed to this event (Arntz 1984, Lee et al. 1995, Tsai et al. 1996, 1997, Connolly and Roughgarden 1999). By this reason, the unusual abundances in K. pelamis and O. libertate during El Niño, both pelagic species, and predator-prey, it could represent the best example in the displacement toward coastal waters during the warm period to pursuit food sources (Godinez-Dominguez et al. 2000).

Finally, all these environmental changes caused by the ENSO event had effects that could be considered from moderate to severe, both ecological and economically. From the ecological point of view, the changes in the composition can have effect in the food chains, mainly due to the intrusion of a bigger number of species and, in the case of the coastal fish, the considerable increase in the abundance of some species of the family Carangidae, which has been identified as extremely voracious, and whose feeding is based on juvenile and adults of many fish species.

From the economic point of view, fishing is one of the economic activities most severely affected by the El Niño event. The preliminary estimates of the Food and Agriculture Organizations of the United Nations (FAO) show that the world production of food registered a decrease from 2 to $4 \%$ during 1997, being expected an increase for 1998 (LluchCota et al. 1999). The East Pacific fisheries, including Mexican fisheries, are significantly impacted during El Niño event, because they are in the area of direct influence. So, Peru suffered a decrease during 1997 that almost reached 60\%, with similar values during 1998 (Duffy and Bryant 1998). For the case of Mexico, official reports still do not exist, although it is known that the impacts were severe, mainly in the Pacific. The changes in the Pacific mean serious losses for our country, since these coasts are the biggest contribution to the national production in terms of volume and production value.
About the species that showed some increase during the ENSO event, as $C$. caninus, C. sexfasciatus, K. pelamis, E. affinis, all these are species that has little economic value in the area, that do not reach higher prices than 1.00 US $\$ / \mathrm{kg}$. They are considered as third quality, and generally used as bait; on the other hand the species that could be in turn worst affected, as H. flaviguttatum, L. guttatus, L. argentiventris, are considered as species of second and first quality, and they can reach prices of 3.00 and $5.00 \mathrm{US} \$ / \mathrm{kg}$, involving the greater losses.

\section{ACKNOWLEDGMENTS}

The authors thank Daniel and Gerardo Kosonoy for designing the gillnet and for fishing operations. Jorge Rojo was supported by the CONACYT and PROMEP Doctorate Scholarship. The English version was reviewed by Cristina Ber nardez (Univ. Coruña, Spain). Casimiro Quiñones is member of COFAA and EDI.

\section{RESUMEN}

Se llevaron a cabo 219 días de pesca experimental en la Bahía de Navidad, Jalisco, México. Se utilizaron cuatro redes de enmalle de diferente luz de malla (76.2, 88.9, 101.6 and $114.3 \mathrm{~mm}$ de luz de malla), de abril de 1994 a marzo de 1995 y de enero de 1998 a diciembre de 2000. En total se capturaron 26126 organismos que pesaron 11680 kg. Fueron identificadas 183 especies pertenecientes a 57 familias y 19 órdenes. Diez especies acumularon más del $60 \%$ de la abundancia y biomasa total, el resto de las especies (173) individualmente aportaron menos del 2\% de la abundancia y biomasa total. Las especies más importantes en la captura fueron Microlepidotus brevipinnis, Caranx caballus, Haemulon flaviguttatum, Scomberomorus sierra, C. caninus, C. sexfasciatus, Lutjanus guttatus y L. argentiventris. La captura por unidad de esfuerzo mostró una gran variación durante todo el periodo de estudio, tanto en número de organismos como en biomasa. En promedio se capturaron 110 organismos/día de pesca $(48.5 \mathrm{~kg} /$ día de pesca). Los valores máximos se registraron durante enero y octubre de 1998 (250 peces y $100 \mathrm{~kg}$ por día de pesca), y el mínimo se registró durante septiembre y noviembre de 1994 (25 organismos y $10 \mathrm{~kg}$ por día de pesca). La abundancia y biomasa total fue menor durante el periodo 1994-1995 $(F=6.16,8.32, P<0.05)$. Se encontraron diferencias estadísticamente significativas entre la captura 
anual de las diferentes redes. Los cambios ambientales provocados por el evento ENOS tuvo efectos que pudieran considerarse de moderados a severos, tanto ecológicos como económicos.

Palabras clave: México, Jalisco, composición específica de peces, pesquería artesanal, El Niño Oscilación del Sur, captura por unidad de esfuerzo

\section{REFERENCES}

Abitia-Cárdenas, L.A., J. Rodríguez-Romero, F. GalvánMagaña, J. De La Cruz- Agüero \& H. Chávez-Ramos. 1994. Lista sistemática de la ictiofauna de Bahía de la Paz, South Baja California, Mexico. Cienc. Mar. 20: 159-181.

Aguilar-Palomino, B., C. Pérez-Reyes, F. Galván-Magaña \& L.A. Abitia-Cárdenas. 2001. Ictiofauna de la Bahía de Navidad, Jalisco, Mexico. Rev. Biol. Trop. 49: 173-190.

Allen, G.R. \& D.R. Robertson. 1994. Fishes of the tropical eastern pacific. Univ. of Hawaii, Honolulu, Hawaii, USA.

Arntz, W.E. 1984. El Niño and Peru positive aspects. Oceanus 27: 36-39

Arntz W.E. \& E. Fahrbach, 1996. El Niño: Experimento climático de la naturaleza. Sección de Obras de Ciencia y Tecnología. Fondo de Cultura Económica, Mexico, Mexico.

Auster, P.J. 1988. A review of present state of understanding of marine fish communities. J. Northwest Atl. Fish. Sci. 8: 67-75.

Brander, K. 1988. Multispecies fisheries of the Irish Sea, p. 303-328. In J. Gulland (Ed). Fish Populations Dynamics ( $2^{\text {nd }}$ Ed). Wiley, New York, New York, USA.

Brodeur, R.D. \& D.M. Ware. 1995. Interdecadal variability in distribution and catch rates of epipelagic nekton in the Northeast Pacific Ocean, p. 329-356. In R.J. Beamish (Ed). Climate change and northern fish populations. Can. Spec. Publ. Fish. Aquat. Sci. 121.

Changnon, S.A. 2000. What made El Niño 1997-1998 famous?, p. 3-27. In S.A. Changnon (Ed). El Niño 1997-1998. The climate event of the century. Oxford University, Oxford, England.
Chávez, F.P., P.G. Strutton, G.E. Friederich, R.A. Feely, G.C. Feldman, D.G. Foley \& M.J. McPhaden. 1999. Biological and chemical responses of the Equatorial Pacific Ocean to the 1997-98 El Niño. Science 286: 2126-2131.

Clarke, K. R. \& R. M. Warwick. 1994. Change in Marine Communities: An approach to Statistical Analysis and Interpretation. Plymouth Marine Laboratory. Plymouth, England.

Connell, J.H. 1978. Diversity in tropical rainforests and coral reefs. Science 199: 1302-1310.

Connolly, S.R. \& J. Roughgarden. 1999. Increased recruitment of northeast-Pacific barnacles during the 1997 El Niño. Limnol. Oceanogr. 44: 466-469.

De la Cruz-Agüero, G. 1994. ANACOM. Sistema para el análisis de Comunidades. Manual del usuario. La Paz, B.C.S., Mexico.

De la Cruz-Agüero, J., F. Galván-Magaña, L.A. AbitiaCárdenas, J. Rodríguez-Romero \& F.J. Gutiérrez. 1994. Lista sistemática de los peces marinos de Bahía Magdalena, B.C.S., Mexico. Cienc. Mar. 20: 17-31.

Francis, R.C. \& S.R. Hare. 1994. Decadal-scale regime shifts in the large marine ecosystems of the Northeast Pacific: a case for historical science. Fish. Oceanogr. 3: $279-291$

Gaston, K.J. 2000. Global patterns in biodiversity. Nature 405: 220-227.

Gobert, B. 2000. Comparative assessment of multispecies reef fish resources in the Lesser Antilles. Fish. Res. 44: $247-260$.

Godínez-Domínguez, E., J.A. Rojo-Vázquez, V.H. GalvánPiña \& B. Aguilar-Palomino. 2000. Changes in the structure of a coastal fish assemblage exploited by a small scale gillnet fishery during an El Niño-La Niña event. Estuar. Coast. Shelf Sci. 51: 773-787.

González, J.A., J.I. Santana, V. Rico, V.M. Tuset \& M.M. García-Díaz. 1995. Descripción de la pesquería de enmalle en el sector Norte Noreste de Gran Canaria. Inf. Tec. Inst. Cienc. Mar. No 1. Telde, Gran Canaria, Spain.

Harris, A.N. \& I.R. Poiner. 1991. Changes in species composition of demersal fish fauna of Southeast Gulf of Carpentaria, after 20 years of fishing. Mar. Biol. 111: 503-519. 
Hollowed, A.B. \& W.S. Wooster 1995. Decadal-scale variations in the eastern Subarctic Pacific: II. Response of Northeasr Pacific fish stocks, p. 373-385. In R.J. Beamish (Ed). Climate change and northern fish populations. Can. Spec. Publ. Fish. Aquat. Sci. No 121.

Hyndes, G.A., M.E. Platell, I.C. Potter \& R.C.I. Lenanton. 1999. Does the composition of the demersal fish assemblages in temperate coastal waters change with depth and undergo consistent seasonal changes?. Mar. Biol. 134: 335-352.

Lee, M.A., K.T. Lee \& G.Y. Shiah.1995. Environmental factors associated with the formation of larval anchovy fishing ground in coastal waters of southwestern Taiwan. Mar. Biol. 121: 621-625.

Lehodey, P., M. Bertignac, J. Hampton, A. Lewis \& J. Picaut. 1997. El Niño Southern Oscillation and tuna in the western Pacific. Nature 389: 715-718.

Lindeman, K.C. \& D.B. Snyder, 1999. Nearshore hardbottom fishes of southeast Florida and effects of habitat burial caused by dredging. Fish. Bull. 97: 508-525.

Lluch-Cota, D., D. Lluch-Belda, S. Lluch-Cota, J. LópezMartínez, M. Nevárez-Martínez, G. Ponce-Díaz, G. Salinas-Zavala, A. Vega-Velázquez, J.R. Lara-Lara, G. Hammann \& J. Morales. 1999. Las pesquerías y El Niño, p. 137-178. In V.O. Magaña (ed.). Los impactos de El Niño en México. Sep-Conacyt-IAI, México D.F., Mexico.

Loneragan, N.R. \& I.C. Potter. 1999. Factors influencing community structure and distribution of different lifecycle categories of fishes in shallow waters of a large Australian estuary. Mar. Biol. 106: 25-37.

Longhurst, A.R. \& D. Pauly. 1987. Ecology of tropical oceans. Academic, London, England.

Madrid-Vera, J. \& P. Sánchez. 1997. Patterns in marine fish communities as shown by artisanal fisheries data on the shelf off Nexpa River, Michoacan, Mexico. Fish. Res. 33: 149-158.

Magaña, V. \& C. Morales. 1999. El clima y la sociedad, p. 1-21. In V.O. Magaña (ed.). Los impactos de El Niño en México. Sep-Conacyt-IAI, Mexico, Mexico.

McPhaden, M.J. 1999. The child prodigy of 1997-98 Nature 398: 559-562.

Parrish, J.D. 1989. Fish communities of interacting shallow-water habitats in tropical oceanic regions. Mar. Ecol. Prog. Ser. 58: 143-160.
Pauly, D. \& G. Murphy, 1982. Theory and management of tropical Fisheries. Manila: ICLARM. Conference Proceedings, 9.

Philander, S.G.H. 1999. A review of tropical ocean-atmosphere interactions. Tellus. 51: 71-90.

Rojo-Vázquez, J.A. \& M.E. Ramírez-Rodríguez. 1997. Composición específica de la captura de redes de enmalle en Bahía de Navidad, Jalisco, México. Oceánides 12: 121-126.

Rojo-Vázquez, JA., F. Arreguín-Sánchez, E. GodínezDomínguez \& M.E. Ramírez-Rodríguez. 1999. Selectividad de redes de enmalle para el pargo Lunarejo (Lutjanus guttatus) y el pargo amarillo (Lutjanus argentiventris) en Bahía de Navidad, Jalisco, México. Cienc. Mar. 25: 145-152

Rojo-Vázquez, JA., F. Arreguín-Sánchez \& E. GodínezDomínguez. 2001. Fishing power, efficiency and selection of gillnets for the shrtfin grunt (Microlepidotus brevipinnis Steindachner, 1869) in the southern coast of Jalisco, Mexico. Rev. Biol. Mar. Oceanog. 36: 9-14.

Sainsbury, K. 1982. The ecological basis of tropical fisheries management. p. 167-188. In Pauly, D. \& G. Murphy, (Eds). Theory and management of tropical Fisheries: Manila: ICLARM. Conference Proceedings, 9, Manila, Phillipines.

Seckel, G. \& K.D. Waldron, 1960. Oceanography and the hawaian skipjack fishery. Pacific Fisherman 2: 1-18.

Sharp, G.D. 1992. Fishery catch records, ENSO, and Longer Term Climate Change as Inferred from Fish Remains From Marine Sediments, p. 379-417. In H. Diaz \& V. Markgraf (eds.). Paleoclimatology of El Niño - Southern Oscillation. Cambridge University, Cambridge, England.

Sherman, K. \& L. Alexander. 1986. Variability and Management of Large Marine Ecosystems. American. Society for the Advancement of Science selected Symposium Series. No. 99. Blackwell Publishing. Boston, Massachusetts, USA.

Trenberth, K.E. 1997. The definition of El Niño. Bull. Am. Meteorol. Soc. 78: 2 771-2 777.

Tsai, C.F., Chen, P.Y., Lee, M.A.., Shiah, G.Y \& K.T. Lee. 1996. Effects of fishing effort on stock size and catch of larval anchovy in coastal waters of southwestern Taiwan. Fish. Res. 28: 71-83. 
Tsai, C.F., P.Y. Chuen, C.P Chen, M.A. Lee, G.Y. Shiah \& K.T. Lee. 1997. Fluctuations in abundance of larval anchovy and environmental conditions on coastal waters off South-western Taiwan as associated with the El Niño-Southern Oscillation. Fish. Oceanogr. 6: $238-249$.

Vanderklift, M.A. \& C.A. Jacoby. 2003. Patterns in fish assemblages 25 years after major seagrass loss. Mar. Ecol. Prog. Ser. 247: 225-235
Zar, J.H. 1999. Biostatistical analysis. Prentice Hall, Englewood Cliffs, New Jersey, USA

\section{INTERNET REFERENCE}

Duffy, D. \& P.J. Bryant, 1998. The 1997-98 El Niño/ Southern Oscillation (ENSO 97-98)- One of the most severe ENSO events in history? Electronic page. University of California in Irving (darwin.bio.uci. edu/ sustain/ENSO.html) Downloaded 21 April 2007. 